Original Research Paper

\title{
Identification of Parasitic Worm Eggs in Cow Feces from Sepang Bay, Lembar District, West Lombok Regency, West Nusa Tenggara
}

\author{
Ahmad Jupri ${ }^{1 *}$ \& Nina Nurraudatul Jannah ${ }^{2}$ \\ ${ }^{1}$ Program Studi Ilmu Lingkungan, FMIPA Universitas Mataram, Indonesia \\ ${ }^{2}$ Program Studi Biologi,FMIPA Universitas Mataram, Indonesia
}

\author{
Article History \\ Received : September $18^{\text {th }}, 2021$ \\ Revised : October $27^{\text {th }}, 2021$ \\ Accepted : November $03^{\text {th }}, 2021$ \\ Published : November $13^{\text {th }}, 2021$ \\ *Corresponding Author: \\ Ahmad Jupri, \\ Program Studi Ilmu Lingkungan, \\ FMIPA Universitas Mataram, \\ Indonesia; \\ Email: juprizikril@gmail.com
}

\begin{abstract}
Cows are one of the ruminant animals and farm animals that have a higher economic value compared to other livestock such as chickens, goats, buffalo and others, so many people build cattle farming businesses. In this case, the health of farm animals is one of the main factors that determine the successful production of cows. The study aims to detect the type of eggs from parasitic worms in cow feces and the degree of infection based on Total Standard (Egg Per Gram). Fecal sampling is done randomly from traditional breeder cows in Teluk Sepang Lembar Subdistrict. The sample number of 10 community cattle farms. Identification of the type of worm was carried out at UPTD Animal Hospital and Veterinary Laboratory of Animal Husbandry and Animal Health Office of West Nusa Tenggara Province. Furthermore, quantitative examination uses the buoyant method (Flotation method) and qualitatively with the Mc. Master method that calculates the number of eggs per gram (EPG) of feces. The results showed 6 negative samples and 4 positive samples infected with parasitic worms, and 2 types of worm eggs of the nematode class namely Trichostrongylus sp. and Chabertia ovina, and 1 species of cestoda class namely Moniezia sp. Based on the standard total EPG (Egg Per Gram) feces it is known that the degree of infection of the type of worm eggs Trichostrongylus sp., Chabertia ovina and Moniezia sp. It is low level.
\end{abstract}

Keywords: Cows, Feces, Parasites and Worm Eggs.

\section{Pendahuluan}

Ternak sapi biasaya dipelihara dengan cara dikandangkan secara terus-menerus (kereman) dan diberi pakan hijauan (rumput dengan pakan tambahan konsentrat) atau digembalakan di padang penggembalaan (padang rumput yang luas, seperti di Nusa Tenggara Barat, Nusa Tenggara Timur, Sulawesi Selatan dan Nanggroe Aceh Darussalam), pada malam harinya sapi ditempatkan pada suatu lokasi yang diberi pagar, tetapi terdapat sapi yang dipelihara di lokasi pembuangan akhir (LPA) untuk mengurangi sampah organik di lokasi tersebut sekaligus dapat menghemat pengeluaran untuk biaya pakan (Sugeng, 2000).

Faktor yang menyebabkan penurunan jumlah produksi ternak salah satunya yaitu gangguan kesehatan yang biasanya disebabkan oleh: bakteri, virus, dan parasit (Pradana et al.,
2015). Penyakit yang sering diabaikan oleh peternak adalah penyakit yang disebabkan oleh parasit cacing. Dari segi ekonomi penyakit yang disebabkan oleh parasit cacing akan menyebabkan kerugian yang sangat tinggi bagi peternak (BPTP NTB, 2011). Terlebih jika cacing tersebut menyebabkan penyakit zoonosis, selain kerugian ekonomi kesehatan mereka juga terancam (Medicastore, 2011).

Berdasarkan survei di beberapa pasar hewan di Indonesia, menunjukkan bahwa 90\% hewan ternak sapi dan kerbau mengidap penyakit cacingan, Penyebab penyakit cacingan antara lain: konsumsi hijauan yang masih berembun dan tercemar vektor pembawa cacing (Nofyan et al., 2010). Penyakit yang disebabkan dari golongan Helminth atau golongan cacing yang menyerang sapi merupakan gangguan kesehatan utama yang mencapai 35\% (Susanti dan Prabowo, 2013). 
Salah satu permasalahan penting yang dihadapi hingga saat ini dalam upaya peningkatan kualitas dan kuantitas ternak sapi di Pulau Lombok adalah masih tingginya tingkat infeksi cacing nematoda parasit. Penyakit helminthiasis (nematodiasis) sebagai salah satu penyakit yang tersebar luas pada ternak di Pulau Lombok (Astiti, et. al., 2018).

Infeksi cacing parasit usus pada sapi, domba, dan kerbau akan mengurangi fungsi kemampuan mukosa usus dalam transpor glukosa dan metabolit. Apabila ketidak seimbangan ini cukup besar akan menyebabkan menurunnya nafsu makan, dan tingginya kadar nitrogen di dalam tinja yang dibuang karena tidak dipergunakan. Akibatnya keterlambatan pertumbuhan akan terjadi, terutama pada ternak muda pada masa pertumbuhan. Oleh karena itu infeksi cacing parasit usus akan bersifat patogenik, terutama jika bersamaan dengan kondisi pakan ternak yang buruk (Muthiadin et al., 2018). Kejadian infeksi cacing pada manusia cukup tinggi khususnya masyarakat yang berternak dengan pola tradisional dimana peternak kontak langsung dengan sapi dan kotorannya. Penyakit yang ditimbulkan pada manusia adalah visceral larva migrans (Medicastore, 2011).

\section{Bahan dan Metode}

Pengambilan sampel feses sapi dilakukan secara acak dari sapi para peternak tradisional di dusun Teluk Sepang Desa Jembatan Gantung Kecamatan Lembar kabupaten Lombok Barat NTB. Pengamatan dan pemeriksaan sampel feses sapi dilakukan di UPTD Rumah Sakit Hewan dan Laboratorium Veteriner Dinas Peternakan dan Kesehatan Hewan Provinsi NTB. Penelitian dilaksanakan selama 1 bulan pada bulan Juli 2021.

Metode yang digunakan untuk pemeriksaan telur cacing parasit pada feses sapi adalah metode apung atau flotasi yang merupakan salah satu dari pemeriksaan kualitatif dalam pemeriksaan feses yang berfungsi dalam menentukan positif atau negatif adanya cacing parasit. Pemeriksaan dengan metode ini biasanya menggunakan larutan $\mathrm{NaCl}$ jenuh atau larutan gula yang didasarkan atas berat jenis telur cacing parasit yang lebih ringan dari berat jenis larutan sehingga telur cacing akan mengapung dan mudah diamati (Tierney,et al., 2002). Dan pemeriksaan secara kualitatif menggunakan metode Mc. Master untuk menentukan jumlah telur per gram (EPG) feses.

Alat-alat yang digunakan antara lain adalah densy meter, satu set alat Whitlock, syringe $10 \mathrm{cc}$, silinder pencampur $100 \mathrm{cc}$, alat pengaduk feses, tabung penyaring, pipet Pasteur, slide kamar penghitung telur cacing/Chamber slide. Bahanbahan yang diperlukan dalam pengujian ini antara lain adalah air, larutan garam jenuh, dan 10 sampel feses sapi (Saraswati et al., 2019).

Metode apung yang digunakan dalam pemeriksaan telur cacing adalah pengapungan dengan metode Whitlock. Feses diambil sebanyak 3 gram kemudian masukan kedalam syringe pengukur lalu tambahkan $7 \mathrm{cc}$ air, sehingga volume di syringe menjadi 10cc. Di masukan seluruh isi dari syringe tersebut ke dalam silinder pencampur (mixing cylinder) yang berisi $50 \mathrm{cc}$ larutan garam jenuh. Aduk feses yang telah berada di dalam larutan garam jenuh sampai tercampur merata dengan menggerakan alat pengaduk secara pelan pelan, naik turun. Tabung penyaring di masukan ke dalam silinder pencampur. Segera ambil larutan feses yang telah tersaring dengan menggunakan pipet Pasteur. Larutan feses yang ada di dalam pipet di masukan ke dalam slide kamar penghitung telur lalu diperiksa dibawah mikroskop (Saraswati et al., 2019). Sampel feses sapi yang positif dapat ditentukan jika ditemukan telur cacing parasit pada kotak kamar hitung telur/chamber slide. Hasil pemeriksaan 10 sampel feses sapi dengan metode apung adalah 6 sampel negatif dan 4 sampel yang positif terinfeksi telur cacing.

Menurut Roeswandono (2019) jumlah telur cacing per gram (EPG) yang ditemukan pada 4 sampel feses sapi yang positif dapat dihitung menggunakan rumus dibawah ini:

$$
\begin{aligned}
& \text { Egg Per Gram }(\mathrm{EPG})=\mathrm{n} \times 50 \\
& \text { Keterangan : } \\
& \mathrm{n}=\text { jumlah telur cacing dalam chamber } \\
& \text { slide }
\end{aligned}
$$

Menurut Bowman (2002), standar Total EPG (Egg Per Gram) pada feses dapat digunakan sebagai penduga berat atau ringannya derajat infeksi, derajat keparahan infeksi tergantung jumlah telur cacing yang menginfeksi 4 sampel feses sapi yang positif yang dapat dilihat pada tabel dibawah ini: 
Tabel 1. Derajat Infeksi Berdasarkan Standar Total EPG

\begin{tabular}{|l|l|l|}
\hline No & $\begin{array}{l}\text { Total EPG (Egg Per } \\
\text { Gram)feses }\end{array}$ & Derajat Infeksi \\
\hline 1 & $1-199$ & Ringan (Low) \\
\hline 2 & $200-999$ & $\begin{array}{l}\text { Sedang } \\
\text { (Intermediet) }\end{array}$ \\
\hline 3 & $>1000$ & Berat (Heavy) \\
\hline
\end{tabular}

\section{Hasil dan Pembahasan}

\section{Kondisi peternakan dan kandang sapi di lokasi penelitian}
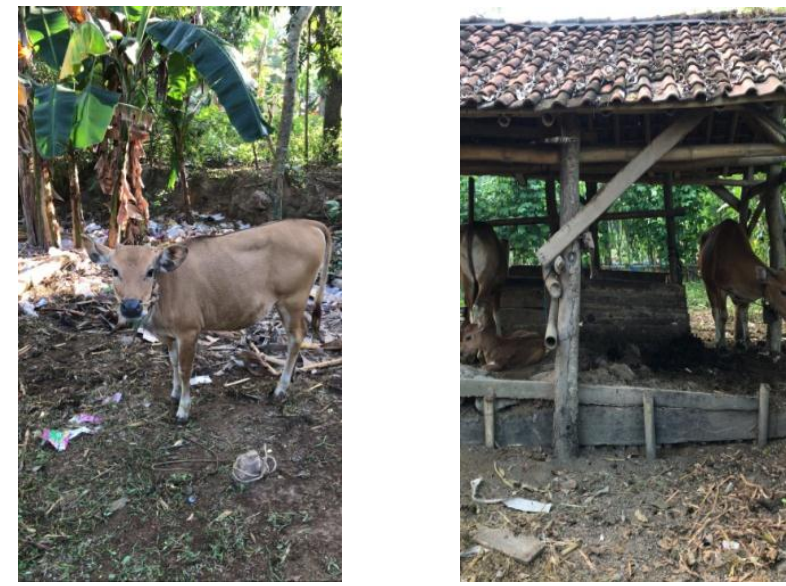

Gambar 1. Foto kondisi kandang sapi di lokasi penelitian
Pada gambar diatas dapat dilihat bahwa kondisi kandang ternak sapi di lokasi penelitian kurang bersih dan berada di lingkungan sekitar pembuangan sampah. Pola pemberian pakan, faktor-faktor lingkungan (suhu, kelembapan, dan curah hujan), serta sanitasi kandang yang kurang baik dapat mempengaruhi berkembangnya parasit khususnya cacing saluran pencernaan pada hewan ternak (Dwinata, 2004).

\section{Hasil pemeriksaan sampel feses sapi dengan metode apung}

Hasil pemeriksaan berupa hasil identifikasi telur cacing yang ditemukan pada 4 sampel yang positif terinfeksi telur cacing parasit dari kelas nematoda yaitu Trichostrongylus sp. dan Chabertia ovina dan dari kelas cestoda yaitu Moniezia sp. yang disajikan pada tabel 2 hasil pemeriksaan dan identifikasi pada sampel feses sapi dibawah ini.

Tabel 2. Hasil Pemeriksaan dan Identifikasi pada Sampel Feses Sapi

\begin{tabular}{|c|c|c|c|c|}
\hline Sampel ke- & $\begin{array}{c}\text { Hasil Pemeriksaan } \\
\text { (positif/negatif) }\end{array}$ & Jenis Parasit & Jumlah & $\begin{array}{c}\text { Hasil hitung EPG } \\
\text { (Egg Per Gram) }\end{array}$ \\
\hline 1 & Positif & Trichostrongylus sp. & 1 & 50 \\
\hline 2 & Negatif & - & - & - \\
\hline 3 & Negatif & - & - & - \\
\hline 4 & Negatif & - & - & 50 \\
\hline 5 & Positif & Chabertia ovina & 1 & 50 \\
\cline { 3 - 5 } & & Moniezia sp. & 1 & 50 \\
\cline { 2 - 5 } & & Trichostrongylus sp. & 1 & 150 \\
\hline 6 & Positif & Trichostrongylus sp. & 3 & - \\
\hline 7 & Negatif & - & - & 50 \\
\hline 8 & Positif & Trichostrongylus sp. & 1 & - \\
\hline 9 & Negatif & - & - & - \\
\hline 10 & Negatif & - & - & \\
\hline
\end{tabular}

Jenis telur cacing parasit pada sampel feses sapi Berdasarkan hasil pemeriksaan dan identifikasi pada 10 sampel feses sapi diatas, terdapat 6 sampel yang negatif dan 4 sampel lainnya positif mengandung telur cacing parasit. Pada semua sampel feses sapi tersebut ditemukan 
2 jenis telur cacing dari kelas nematoda yaitu Trichostrongylus sp., dan Chabertia ovina, dan 1 jenis dari kelas cestoda Moniezia sp

\section{1) Trichostrongylus sp.}

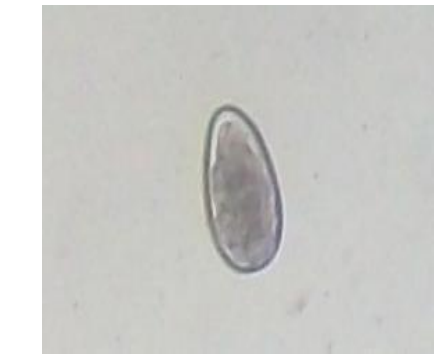

Gambar 1. Trichostrongylus

sp. perbesaran 10x 10

(Paramitha et al., 2017)

Trichostrongylus sp. tergolong cacing giling atau cacing nematoda sehingga disebut nematoda gastrointestinal (Hanafiah et. al., 2002). Cacing ini lebih dikenal dengan cacing rambut karena ukurannya yang kecil. Cacing ini berpredileksi pada usus halus dari hewan ruminansia besar, kecuali Trichostrongylus axei hidup di dalam abomasum ruminansia peliharaan dan iar di dalam lambung serta usus kecil kuda. Cacing Trichostrongylus di temukan dalam jumlah lebih banyak selama musim kering di bandingkan musim basah hal ini di dukung oleh faktor lingkungan terutama musim kering perkembangan telur cacing Trichostrongylus tidak begitu banyak memerlukan air berbeda dengan cacing Fasciola sp. yang dalam siklus hidupnya memerlukan inang perantara yakni berupa siput air serta rumput yang hidup dalam genangan air (Soulsby, 1986). Patogenesis pada hewan muda lebih hebat dari pada hewan dewasa. Gejala klinis dari hewan terinfeksi cacing Trichostrongylus sp adalah terjadi penurunan nafsu makan, anemia ,berat badan menurun, diare, pembengkakan dan perdarahan mukosa, bahkan sampai kematian ( Soulsby, 1986 ).Berdasarkan hasil hitung jumlah EPG (Egg Per Gram) dengan metode Mc. Master pada feses sapi yang positif terinfeksi Trichostrongylus sp. yang ditemukan pada 4 sampel feses sapi berkisar antara 50-150. Berdasarkan Standar Total EPG, derajat infeksi dari Trichostrongylus sp. tergolong rendah.

\section{2) Chabertia ovina}

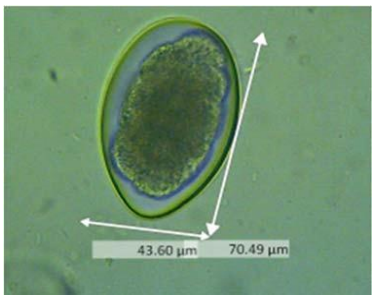

Gambar 2. Chabertia ovina perbesaran 10x10 (Puspitasari et al., 2019)

Chabertia ovina merupakan jenis cacing dari kelas nematoda yang ditemukan pada sampel feses sapi. Infeksi yang disebabkan oleh Chabertia ovina disebut Chabertiasis dengan predileksi pada saluran pencernaan. (Suwanti et al., 2012). Infeksi akibat adanya Chabertia ovina yang tampak yaitu adanya diare dengan feses campur lendir dan darah, kondisi jelek, lemah, penurunan berat badan, anemia, dan melanjut sampai kematian. (Suwanti et al, 2012) Berdasarkan hasil hitung jumlah EPG (Egg Per Gram) dengan metode Mc. Master pada feses sapi, Chabertia ovina yang ditemukan pada setiap sampel feses sapi berkisar antara 50. Berdasarkan Standar Total EPG, derajat infeksi dari Chabertia ovina tergolong rendah.

\section{3) Moniezia sp.}

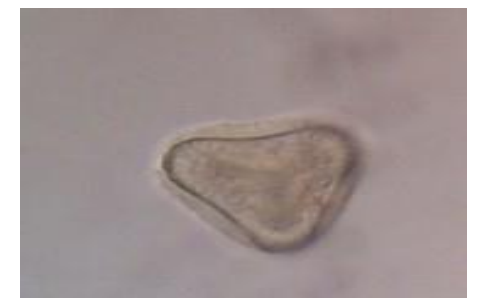

Gambar 3. Moniezia sp. perbesaran 40x10 (Tantri et al., 2013)

Moniezia sp. merupakan genus dari telur cacing parasit dari kelas cestoda yang biasa ditemukan pada usus halus. Siklus hidup dari parasit cacing kelas cestoda membutuhkan induk semang antara,apabila telur cacing termakan induk semang antara maka oncosfer dan embriofor akan hancur oleh aktivitas enzim saluran pencernaan dan kemudian akan menembus dinding usus menuju pembuluh darah dan ikut aliran darah ke predileksi. Ternak sapi akan terinfeksi bila 
memakan rumput yang terdapat mites (tungau) yang mengandung sistiserkoid yang infektif (Koesdarto et al., 2007). Gejala klinis yang disebabkan oleh Moniezia sp. tidak diketahui dengan jelas. Parasit ini bisa didiagnosis dengan proglotid gravid atau karakteristik dari telurnya. Berdasarkan hasil hitung jumlah EPG (Egg Per Gram) dengan metode Mc. Master pada feses sapi, Moniezia sp. yang ditemukan pada sampel feses sapi berkisar antara sebanyak 50. Berdasarkan Standar Total EPG, derajat infeksi dari Moniezia sp. tergolong rendah.

Banyak penyakit lain yang mempunyai gejala klinis mirip, sehingga untuk menetapkan diagnosis hanya dengan melihat gejala klinis sulit dibedakan. Penentuan diagnosis yang tepat dapat dilakukan dengan pemeriksaan feses secara teratur untuk menentukan jenis telur cacing. Diagnosis dapat pula ditentukan dengan pemeriksaan pasca mati dengan menemukan cacing dewasa dan lesi yang ditimbulkan di saluran pencernaan (Suwanti et al., 2012). Dalam menentukan obat yang akan digunakan untuk mengobati infeksi cacing,harus memperhatikan toksisitas terhadap jenis cacing dalam semua stadium.

Adapun upaya penanganan sapi yang terinfeksi dapat diberikan obat cacing secara rutin berupa piperzone atau obat cacing lainnya sesuai anjuran dokter hewan. Untuk pencegahan dapat dilakukan dengan cara membersihkan kandang secara rutin untuk memastikan tidak ada feses yang menumpuk di kandang untuk mencegah penularan melalui kontaminasi oleh feses yang mengandung telur cacing. Selain itu dapat dicegah dengan memberikan pakan yang bersih dan berkualitas agar resiko cacingan pada ternak sapi dapat ditekan.

\section{Kesimpulan}

Pada sampel feses sapi ditemukan jenis telur cacing parasit dari kelas nematoda yaitu Trichostrongylus sp. dan Chabertia sp., dan dari kelas cestoda yaitu Moniezia sp. Berdasarkan hasil hitung EPG (Egg Per Gram) derajat infeksi tiap jenis cacing parasit yang ditemukan pada sampel feses ditentukan melalui Standar Total EPG pada sampel feses sapi. Derajat infeksi dari jenis Trichostrongylus sp. dan Chabertia sp. tergolong infeksi tingkat rendah karena jumlah total EPG kedua jenis cacing ini sebanyak 50. Derajat infeksi dari jenis Moniezia sp. juga tergolong infeksi tingkat rendah karna jumlah total EPG cacing ini sebanyak 50.

\section{Ucapan Terima Kasih}

Ucapan terima kasih penulis sampaikan kepada Unit Pelaksana Teknis Daerah (UPTD) Rumah Sakit Hewan dan Laboratorium Veteriner Dinas Peternakan dan Kesehatan Hewan Provinsi NTB.

\section{Referensi}

Astiti, L. G. S., Panjaitan, T., \& Sriasih, M. (2018). Sebaran Nematodiasis pada Sapi Bali (Bos javanicus d'alton) di Pulau Lombok. Seminar Nasional Percepatan Alih Teknologi Pertanian Mendukung Revitalisasi Pertanian dan Pembangunan Wilayah (pp.1325-1330). Denpasar, Indonesia: Balai Besar Pengkajian dan Pengembangan Teknologi Pertanian, Badan Penelitian dan Pengembangan Pertanian, Kementerian Pertanian.

Bowman, D. D., C. M. Hendrix, D. S. Lindsay and S. C. Barr. (2002). Feline Clinical Parasitology. 1 edition. Lowa: Lowa State University Press.

BPTP NTB. (2011). 15 Jenis Cacing ditemukan pada Sapi Bali di KabupatenBima.http://epetani.deptan.go.id/ budidaya.

Dwinata, M. I. (2004). Prevalensi Cacing Nematoda pada Rusa yang Ditangkarkan. Jurnal Veteriner. 6 (4): 151--155

Hanafiah, Winaruddin, \& Rusli (2002). Studi Infeksi Nematoda Gastrointestinal pada Kambing dan Domba di Rumah Potong Hewan Banda Aceh. Jurnal Sains Veteriner. 20(1): 15-19.

Koesdarto, S., S. Subekti., S. Mumpuni., H. Puspitawati \& Kusnoto (2007). Buku Ajar Ilmu Penyakit Nematoda Veteriner. 
Surabaya: Fakultas Kedokteran Hewan Universitas Airlangga.

Medicastore (2011). Toxocariasis. Infeksi dan Penyakit //medicastore.com/penyakit/220/

Toksokariasis.html).

Muthiadin C., Aziz IR, \& Firdayana (2018). Identifikasi Dan Prevalensi Telur Cacing Parasit Pada Feses Sapi (Bos sp.) Yang Digembalakan Di Tempat Pembuangan Akhir Sampah (Tpas) Tamangapa Makassar. BIOTROPIC The Journal of Tropical biology. 2(1): 1-7.

Nofyan, E, Kamal M, \& Rosdiana I. (2010). Identitas Jenis Telur Cacing Parasit Usus Pada Ternak Sapi (Bos sp) dan Kerbau (Bubalus sp) Di Rumah Potong Hewan Palembang. JurnalPenelitian Sains. 6(10):611.

Paramitha, Ratih P., R. Ernawati., \& Setiawan Koesdarto (2017). Prevalensi Helminthiasis Saluran Pencernaan melalui Pemeriksaan Feses pada Sapi di Lokasi Pembuangan Akhir (LPA) Kecamatan Benowo Surabaya. Journal Of Parasite Science. 1(1):23-32.

Pradana D.P., Haryono T., Ambarwati R. (2015). Identifikasi Cacing Endoparasit pada Feses Ayam Pedaging dan Ayam Petelur. Lentera Bio. 4(2), 119-123.

Puspitasari, A., B. Setiawan., S. Koesdarto., Kusnoto., Soeharsono \& Poedji Hastutiek (2019). The Distribution of Goat Gastrointestinal Tractus Worm Egg at Rambon District of Nganjuk Regency. Journal Of Parasit Science. 3(2):59-66.

Roeswandono, O. R. P. A. Mussa., M. J. A. Pangaribuan., \& B. U. Pangunaldi (2019). Perhitungan Telur Toxocara cati dan Jumlah Sel Darah Putih pada Kucing Liar (Felis catus) di Dukuh Kupang Surabaya. Jurnal Vitek Kedokteran Hewan. 9(1): 18-23.
Saraswati., Yunanto., \& Sutawijaya (2015). Prevalensi Toxocara vitulorum pada Sapi Bali di Wilayah Provinsi Bali. Buletin Veteriner BBVet Denpasar. (86).

Soulsby EJL. (1986). Helminth, Arthropods and Protozoa of Domesticated Animal. 7th Ed. The English Languange Book Socienty and Baillire Tindal. London. 143-256.

Sugeng, B. Y. (2000). Sapi Potong Pemeliharaan, Perbaikan, Produksi Prospek Bisnis Analisa Penggemukan. Jakarta: Penebar Swadaya.Susanti, Aulia Evi dan Prabowo A. 2013. Identifikasi Masalah Kesehatan Sapi Potong di Wilayah Pendampingan PSDSK Provinsi Sumatera Selatan. Seminar Nasional Teknologi Peternakan dan Veteriner. 300-303.

Suwanti, L. T., N. D. R. Lastuti., E. Suprihati, \& Mufasirin (2012). Buku Ajar Ilmu Penyakit Protozoa. Surabaya: Universitas Airlangga.

Tantri, Novese., T. R. Setyawati., \& Siti Khotimah (2013). Prevalensi dan Intensitas Telur Cacing Parasit pada Feses Sapi (Bos Sp.) Rumah Potong Hewan (RPH) Kota Pontianak Kalimantan Barat. Protobiont. 2(2): 102-106.

Tierney, Lawrence M., S. J. McPhee., \& S. Papadakis (2002). Diagnosis dan Terapi Kedokteran Ilmu Penyakit Dalam. Jakarta: Penerbit Salemba Medika. 